MEDICAL EDUCATION AND MANPOWER IN THE EEC 


\title{
MEDICAL EDUCATION AND MANPOWER IN THE EEC
}

\author{
Proceedings of a Symposium \\ organized by Fondazione Smith Kline at \\ Stresa, Italy, 1-4 October 1982
}

Edited by

Professor Sir John Walton, TD, MD, DSc, FRCP Warden, Green College at the Radcliffe Observatory, Oxford, OX2 $6 H G$ Formerly Professor of Neurology and Dean of Medicine University of Newcastle upon Tyne

and

T.B. Binns, FRCP (Lond), FRCP (Edin), FRCP (Glasg), DCH Honorary Senior Lecturer Department of Pharmacology and Therapeutics London Hospital Medical College, London E1 2AD

Published by

THE MACMILLAN PRESS LTD

in association with

FONDAZIONE SMITH KLINE

Milan 
(C) The participants 1984

Softcover reprint of the hardcover 1st edition 1984 978-0-333-36366-9

All rights reserved. No part of this publication may be reproduced or transmitted, in any form or by any means, without permission

First published 1984 by

The Scientific and Medical Division

THE MACMILLAN PRESS LTD

London and Basingstoke

Companies and representatives throughout the world

in association with

FONDAZIONE SMITH KLINE

Milan, Italy

British Library Cataloguing in Publication Data

Medical education and manpower in the EEC.

1. Medical education-European Economic Community countries-Congresses

I. Walton, Sir John, 1922-

II. Binns, Terry

610'.7'114 R772

ISBN 978-1-349-07055-8 ISBN 978-1-349-07053-4 (eBook)

DOI 10.1007/978-1-349-07053-4 


\section{Contents}

Participants vii

Preface $\quad$ ix

Fondazione Smith Kline $\quad$ xi

1 MEDICAL DEMOGRAPHY: A LOOMING ISSUE. THE CASE OF ITALY A. Brenna 1

2 MEDICAL DEMOGRAPHY, MEDICAL EDUCATION AND THE EEC D. Deliege 15

3 Discussion 33

4 ADMISSION TO THE STUDY OF MEDICINE IN BELGIUM A. Castermans

5 WHAT LEVEL OF ACADEMIC ACHIEVEMENT AND WHAT PERSONALITY CHARACTERISTICS SHOULD INTENDING MEDICAL STUDENTS POSSESS? P.N. Meenan 53

6 Discussion opened by $B$. Sorensen $\quad 59$

7 THE OBJECTIVES OF BASIC MEDICAL EDUCATION: I J. Borde

8 THE OBJECTIVES OF BASIC MEDICAL EDUCATION: II K. Hinrichsen

9 THE OBJECTIVES OF BASIC MEDICAL EDUCATION: III. THE MAASTRICHT PRINCIPLE J.M. Greep $\quad 89$

10 Discussion $\quad 97$

11 MEDICAL NEEDS AND THE AVAILABILITY OF DOCTORS: CONDITIONS IN FRENCH REGIONS

S. Sandier 
vi Contents

12 HOW CAN THE NUMBERS OF DOCTORS REQUIRED TO SATISFY THE HEALTH-CARE NEEDS OF A POPULATION BE DEFINED? J. Parkhouse

13 REALITIES IN HEALTH MANPOWER PLANNING IN THE NETHERLANDS J.M. Greep

14 Discussion opened by F.F. Rutten

15 PRINCIPLES GOVERNING TRAINING PROGRAMMES FOR INDIVIDUAL SPECIALTIES IN MEDICINE: I

D. McCarthy

16 PRINCIPLES GOVERNING TRAINING PROGRAMMES FOR INDIVIDUAL SPECIALTIES IN MEDICINE: II U. Muscatello

17 Discussion

18 MEDICAL AUDIT: I. IS IT NEEDED AND HOW SHOULD IT BE DONE? A. Maynard

19 MEDICAL AUDIT: II S.A. Doxiadis

20 Discussion opened by K.M. Pedersen; F.F. Rutten

21 CONTINUING EDUCATION IN MEDICINE: I A. Maynard 209

22 CONTINUING EDUCATION IN MEDICINE: II G. Meisch 215

23 Discussion

24 CLOSING SESSION - SUMMARY 


\title{
Participants
}

\author{
Professor Sir John Walton (Chairman)* \\ Professor of Neurology, University of Newcastle \\ Regional Neurological Centre \\ Newcastle General Hospital \\ Newcastle upon Tyne, NE4 6BE \\ UK
}

\author{
Professor J. Borde \\ Clinique Chirurgicale Infantile \\ Hôpital Charles-Nicolle \\ Boulevard Gambetta \\ 76031 Rouen \\ France
}

Professor A. Brenna

Istituto di Economia Sanitaria

Corso Magenta, 42

20123 Milan

Italy

Professor U. Carcassi (Auditor)

Direttore Istituto di Clinica

Medica 1

Member of the Association of

Medical Deans in Europe

Via San Giorgio, 12

09100 Cagliari

Italy

Professor A. Castermans

Hôpital de Bavière

Université de Liège

Bd de la Constitution, 66

4000 Lieg̀e

Belgium

*See $p$. iii for present address.
Professor D. Deliege

Université de Louvain

Faculté de Médicine

École de Santé Publique

Clos Chapelle-aux Champs, 30.41

1200 Brussels

Belgium

Professor S. Doxiadis

President, Institute of Child Health

Aghia Sophia Children's Hospital

3, Neophytou Vamva Street

Athens 138

Greece

Professor U. Göbel

Planungsgruppe Medizin

Im Neuenheimer Feld 346

6900 Heidelberg

West Germany

Professor Dr J. M. Greep

Dean, Faculty of Medicine

P.O. Box 616

6200 MD Maastricht

The Netherlands 
Professor Dr K. Hinrichsen

Lehrstuhl für Anatomie 1

Ruhr-Universität

Postfach 102148

Universitätsstrasse, 150

4630 Bochum 1

West Germany

Mr D. McCarthy

Department of Health

Hawkins House

Dublin 2

Ireland

Dr A. Maynard

Department of Economics and Related Studies

University of York

York, YO1 5DD

UK

Professor P. N. Meenan

University College

The Medical School

Earlsfort Terrace

Dublin 2

Ireland

Dr G. Meisch

Association des Médecins et

Médecins-Dentistes

Rue de Vianden, 29

2680 Luxembourg

Luxembourg

Professor U. Muscatello

Istituto dei Patologia Generale dell'Università

Via Campi, 287

41100 Modena

Italy
Professor J. Parkhouse

Regional Postgraduate Institute for

Medicine and Dentistry

11, Framlington Place

Newcastle upon Tyne, NE2 4AB

UK

Professor K. M. Pedersen

Institute of Social Sciences

Odense University

Campusvej, 55

5230 Odense M

Denmark

Professor Dr F. F. H. Rutten

Faculty of Medicine

Health Economics

P.O. Box 616

6200 MD Maastricht

The Netherlands

Professor S. Sandier

Directeur de Recherches

Division d'Économie Médicale

CREDOC

Rue du Chevaleret, 142

75634 Paris, Cedex 13

France

Professor B. Sorensen

Hvidovre Hospital

Kettegärd Alle, 30

DK2650 Hvidovre

Denmark 


\section{Preface}

Many of the issues that have become sources of increasing concern to the medical profession throughout Europe of late have been those relating to medical demography and medical education in the broadest sense. When the Advisory Committee on Medical Training in Europe was established by the EEC some 10 years ago, it became evident that there was considerable variation in the programmes of undergraduate medical education established by the various member countries; and even more particularly, striking discrepancies became apparent in relation to procedures concerned with the admission of students to medical schools and university faculties of medicine. Thus some member countries had for many years adopted a programme of strict control on medical-school entry according to academic and other criteria, in order to make certain as far as possible that the facilities available for training were adequate to educate the students admitted, and also in order to restrict the output of doctors so as to bear some relationship to the healthcare needs of the country. By contrast, in other countries no such numerus clausus had ever been operated, since the political view was strongly held that all young men and women who were capable (according to their school performance) of benefiting from medical education, should be given that opportunity. The result of this policy had been a massive increase in the number of students studying medicine and in the output of doctors. There was also evidence that the increasing establishment of health-care programmes controlled both administratively and financially by government had imposed some restriction upon the development of health services in certain countries, with consequential fears of medical unemployment and wastage of skilled medical manpower, expensively trained usually at public expense. In the European scene, too, significant differences had emerged in relation to the philosophy, content and duration of programmes of training in individual specialties in medicine.

The Stresa symposium, held in October 1982 through the inspiration and initiative of the Fondazione Smith Kline and its Director, Dr Ghetti, brought together a number of experts from many European countries to discuss these problems and to propose some solutions relating to the entire field of medical demography, medical economics, health-care development and education, at 


\section{$\mathrm{x}$ Preface}

both the undergraduate and postgraduate levels. In each session, opening contributions were given by a medical educator on one hand, and by a medical administrator or health-care economist on the other. The extensive and well-informed discussions that followed were recorded and edited. The result, we believe, is a publication of considerable importance and topicality which will be of major interest to doctors throughout Europe who either play some part in medical education at a particular level or who are involved in the organization and planning of health services, as well as to those who are involved in committees concerned with the regulation and delivery of medical education, not only in the EEC, but also throughout Europe. The book should also be invaluable to health-care economists in bringing to their attention medical views as well as those of their colleagues upon controversies of the moment. Hopefully, too, it will appeal to a wider international audience since many of the problems exposed in this volume are being experienced in all developed and developing countries. 


\section{雾}

\section{Fondazione Smith Kline}

The Fondazione Smith Kline is an independent institution founded in 1979 by Smith Kline \& French S.p.A. of Milan, a subsidiary of the Smith Kline Beckman Corporation of Philadelphia, USA.

In this way, the Smith Kline group wishes to show that in Italy, as well as through Smith Kline Foundations elsewhere, it desires to assist with the problems, needs and expectations of the countries in which it is active.

The Fondazione Smith Kline, which was granted legal status by a Presidential Decree dated September 9, 1982 and which operates autonomously, is governed by a Board of Directors which delegates the implementation of its resolutions to an Executive Committee. The areas of interest that have so far received attention are university medical education and health economics. The role of the Fondazione is that of a 'service agency', meeting point, information centre and instrument to facilitate exchanges between academics and other experts in its chosen fields of interest.

The symbol of the Fondazione Smith Kline-a jet of water on a background of a plant structure-is intended to represent the inexhaustible capacity of man to change and develop when he is both sensitive to nature (the plant structure) and attentive to the diffusion of new ideas (the jet of water).

\section{ACKNOWLEDGEMENT}

Grateful acknowledgement is made to Luisa Marchetti for her contribution to the organization, conduct and recording of the meeting. 